Journal of Animal and Veterinary Advances 18 (8): 270-277, 2019

ISSN: 1680-5593

(C) Medwell Journals, 2019

\title{
Effects on Performance, Organic Digestibility and Some Blood Parameters of Use of Wafer in Local Calves Rations as Alternative Feed
}

\author{
Yuli Retnani, Iwan Prihantoro, Anuraga Jayanegara, Idat Galih Permana, M. Royan, \\ Isal Mawardi and Taryati \\ Department of Nutrition and Feed Technology, Faculty of Animal Science, \\ Bogor Agricultural University, Jl. Agatis, Kampus Darmaga, 16680 Bogor, Indonesia
}

\begin{abstract}
Sub-sector of livestock has an important role in the life and development of human resources in Indonesia. An important issue on agribusiness beef cattle is a continuous population decline every year. The application of technology has to be initiated in order to obtain production efficiency and production cost efficiency. One of the factors that affect the productivity of livestock is feed. The major constraints of ruminant feed are low quality of forage, the low level of palatability and digestibility. To solve this problem is making forage waste into wafer feed supplement. The aim of this experiment was to determine the nutrient content on wafer feed supplement and productivity of local calf that were given by wafer feed supplement. This research was conducted at Laboratory of Feed Industry, Bogor Agricultural University and the performance test at Karya Anugrah Rumpin Corporation on March-April 2016. To determine the nutrient content of wafer feed supplements used proximate analysis. The experiment of productivity used 12 heads of male local calves (Sumba Ongol calves) with average body weight around $136 \pm 22.46 \mathrm{~kg}$ with ages around 12-18 months. The experimental local calves were maintained individually. The experimental design used randomized block design with four treatments and three replications. The treatments were feeding patterns of wafer feed supplement i.e., $\mathrm{T} 1=0 \%$ by feeding wafer supplement+concentrate+king grass, $\mathrm{T} 2=10 \%$ by feeding wafer supplement + concentrate+king grass, $\mathrm{T} 3=$ King grass $+10 \%$ by feeding wafer supplement+concentrate, $\mathrm{T} 4=$ Concentrate + king grass $+10 \%$ by feeding wafer supplement. The parameters measured were productivity of local calves, i.e., daily weight gain, final body weight, consumption, dry matter and organic matter digestibility, blood cholestrol, blood glucose, blood protein. It was concluded that feeding pattern wafer feed supplement can increase consumption and not influence condition of local calves. It was concluded that daily weight gain by feeding wafer supplement feed $42-45 \%$ higer than conventional feed. High crude protein of wafer feed supplement is good supplement for ruminant in the tropic.
\end{abstract}

Key words: Feed supplement, local calves, performance, organic digestibility, some blood, parameters, wafer

\section{INTRODUCTION}

Sub-sector of livestock has an important role in the life and development of human resources in Indonesia. This role can be seen from the function of livestock products as a provider of animal protein is essential for growth and development of the human body. Beef consumption per capita in Indonesia in 2016 reached $2.61 \mathrm{~kg}$. This figure is low when compared with other countries in Southeast Asia i.e., Argentina $15 \mathrm{~kg}$ per capita, Singapore $15 \mathrm{~kg}$ per capita and Philippines $7 \mathrm{~kg}$ per capita (Chandra, 2016). Indonesia needs 674.690 ton of beef per year. Only about $65.48 \%$ can be met by domestic beef production and the rest is coming from another country imports (Agustinus, 2016).
An important issue on agribusiness beef cattle is a continuous population decline every year. Consequently meeting the needs of meat by importing cattle and frozen meat. Given these conditions many food exporting countries tend to export their products to be used as stock food. The people will choose the better food quality in animal products. Development of cattle farms is not enough just to increase the population with the government's efforts to provide assistance cattle or business capital. The application of technology has to be initiated in order to obtain production efficiency and production cost efficiency (Retnani et al., 2014). One of the factors that affect the productivity of livestock is feed.

The major constraints of ruminant feed are as follows: low quality of forage; the level of palatability

Corresponding Author: Yuli Retnani, Department of Nutrition and Feed Technology, Faculty of Animal Science, Bogor Agricultural University, Jl. Agatis, Kampus Darmaga, 16680 Bogor, Indonesia 
and digestibility is low. Therefore, it is necessary to develop suitable technologies to produce ruminant feed which is more durable, easier to handle, more convenient to distribute and are available in all season (Retnani et al., 2003). During the rainy season, forage is abundant but during the dry season forage very little or none, so that, the local calves can decrease its productivity (Agustinus, 2016).

To solve this problem is making forage into wafer feed. A pressing technology can make the feed products into a wafer form. The wafer feed must contain energy; Mineral; Vitamin and protein that are needed by animal to increase productivity (Retnani et al., 2010). Wafer of feed supplement is made of fiber, especially, fresh green forage as a replacement for ruminants in order to utilize the fiber when the quality and quantity of forage decreased (Retnani et al., 2014). Composition of wafer feed supplement containing lamtoro leaf. Lamtoro leaf is legume is widely used as animal feed because it has a comparative advantage when compared with other legume. Lamtoro leaf contain high crude protein, i.e., 23.4 and $29.5 \%$ dry matter, $1.3 \%$ crude fiber $4.5 \%$ crude fat $8.2 \%$ ash (Hartadi et al., 1986). Meanwhile the use of excessive lamtoro leaves will cause symptoms fur loss, decreased appetite and alopecia red esophagus caused by the content antinutrisi on lamtoro such as Leucaena mimosin have mimosin content of $2.08-5 \%$ dry matter (Soebarinoto and Mashudi, 1991). Thus before using lamtoro leaf must be processed to decrease antinurtisi. Process of wafer can decrease anti-nutrient of lamtoro leaf because the process by pressing and heating. Composition of lamtoro leaf use of wafer feed supplement are $30 \%$. Other than feed factor which affects the productivity of livestock is a pattern of feeding.

The pattern of feeding is very important to improve livestock productivity. Feeding method with the interval feeding between of concentrates and forages will increase the productivity of livestock (Syahwani, 2004). The pattern feeding with interval every $2 \mathrm{~h}$ between concentrates and forages also, generating microbial synthesis greater than feeding once or twice per day (Soeparno, 1994). Feeding the concentrate $2 \mathrm{~h}$ before the forage will increase dry matter and organic matter digestibility (Siregar, 1995). The concentrate more easily digested will increase the growth of microbes and rumen fermentation process (Devendra and Burns, 1994).

The aim of this experiment was to determine the nutrient content on wafer feed supplement and productivity of local calf that were given by wafer feed supplement. So that, the feeding wafer feed supplement and pattern of feeding can increase productivity of local calf.

\section{MATERIALS AND METHODS}

Process of wafer feed supplement production by chopping, drying, mixing, preassing, heating and forming with temperature $100^{\circ} \mathrm{C}$ for $10 \mathrm{~min}$ to get wafer feed and than cooling in room temperature. Diagram process of wafer feed production shown in Fig. 1.

To determine the nutrient content of wafer feed supplements used proximate analysis. The experiment of productivity used 12 heads of male local calves (Sumba Ongol calves) with average initial body weight around $136 \pm 22.46 \mathrm{~kg}$ with ages around 12-18 months. The experimental local calves were maintained individually. The ration used consisted of two types conventional feed, i.e., king grass and concentrate.

Nutrient content of king grass, i.e., ash $9.4 \%$, crude fat $2.1 \%$, crude protein $10.6 \%$, crude fiber $28.13 \%$, TDN $55.2 \%$. Nutrien content of concentrate, i.e., ash $24.7 \%$, crude fat $4.4 \%$, crude protein $11.5 \%$, crude fiber $10.3 \%$. While nutrient content of wafer feed supplement, i.e., ash $8 \%$, crude fat $4.31 \%$, crude protein $27.4 \%$, crude fiber $8.9 \%$, TDN $81.4 \%$. Nutrient content of conventional feed and wafer feed supplement (\% dry matter) an analysis of the Research Center for Biological Resources and Biotechnology, Institut Pertanian Bogor (2016).

Experimental design: The treatments were feeding patterns of wafer feed supplement, i.e., $\mathrm{T} 1=0 \%$ by feeding wafer supplement+concentrate+king grass, $\mathrm{T} 2=10 \%$ by feeding wafer supplement+concentrate+king grass, $\mathrm{T} 3=$ King grass $+10 \%$ by feeding wafer supplement + concentrate, $\mathrm{T} 4$ $=$ Concentrate + king grass $+10 \%$ by feeding wafer supplement. The data was analyzed with the analysis of

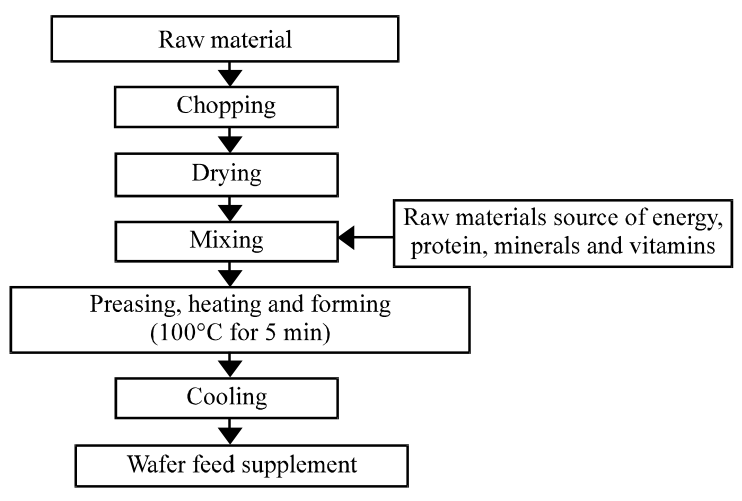

Fig. 1: Diagram process of wafer feed supplement production (Retnani et al., 2014) 
variance and the differences among treatments were examined with orthogonal contrast test (Steel and Torrie, 1993).

The parameters measured were productivity of local calves, i.e., daily weight gain, final body weight, consumption, dry matter and organic matter digestibility, blood cholestrol, blood glucose, blood protein. Daily weight gain was calculated by:

- Daily weight gain was calculated by:

Daily weight gain (g/head/day) $=\frac{\text { Final body weight gain (g)-Initial body weight gain (g) }}{\text { During the research (days) }}$

- Final body weight was calculated by weighing the local calves body weight of the calve every 2 weeks during the research

- Dry matter digestibilty (Tilley and Terry, 1963)

$$
\begin{aligned}
& \text { Dry matter = } \\
& \frac{\text { Dry matter in feed (g)-Dry matter in feces }(\mathrm{g})}{\text { Dry matter in feces }(\mathrm{g})} \times 100 \%
\end{aligned}
$$

- $\quad$ Organic Matter Digestibility

$$
\text { Organic matter }=\frac{\text { Organic matter in feed }(\mathrm{g}) \text {-Organic matter in feed }(\mathrm{g})}{\text { Organic matter in feces }(\mathrm{g})} \times 100 \%
$$

Blood metabolite: Blood glucose was estimated by the method of Folin and Wu (1920). Serum cholesterol and total proteins were analyzed by the modified method of Zak (1957).

\section{RESULTS AND DISCUSSION}

Feed intake: Physical form of wafer feed was a cube with size $5 \times 5 \times 5 \mathrm{~cm}^{3}$. The texture of wafer feed was rough with coarse particle size. During process making wafer feed by heating and pressing did not a decline in nutritional quality (Retnani et al., 2014). Process of wafer can decrease $30 \%$ mimosin of lamtoro leaf. Mimosin is anti-nutrients that can result in stunted growth, low consumption and hair loss.

Wafer feed supplement did not have significant effect $(\mathrm{p}>0.05)$ on consumption of local calves. The average consumption of local calves on percent dry matter (\%) 6.60-7.89 kg/head. Local calves body weight 150$200 \mathrm{~kg}$ with daily weight gain $1.1 \mathrm{~kg} / \mathrm{head} /$ day need dry matter intake $4 \mathrm{~kg} / \mathrm{head}$ (Kearl, 1982). Dry matter consumption was shown in Fig. 2. According local calves with the average body weight of $274 \mathrm{~kg}$ should can consume the feed in the form of dry material as much as $6.85 \mathrm{~kg}$ or $2.5 \%$ of their body weight. Total protein consumption was around $4.65-5.75 \mathrm{~kg} / \mathrm{head} /$ day (Preston and Leng, 1987). The high consumption of crude protein in this study indicated resources a high content of crude protein in wafer feed supplements were $25 \%$ was able to Increase total crude protein consumption. Total protein consumption was shown in Fig. 3 and 4.

Daily weight gain: The result showed that wafer feed supplement treatment had significant effect $(p<0.05)$ on daily weight gain of local calves. Howefer feeding treatment was not significant effect $(p>0.05)$ on block of daily weight gain. Daily weight gain in this study ranged from $0.53-0.97 \mathrm{~kg} / \mathrm{head} / \mathrm{day}$. The daily weight gain of Bali calves was about $0.3 \mathrm{~g} /$ head/day (Zak, 1957). The treatment of T4 was highest daily weigth gain than with other treatments. Feeding pattern wafer supplement treatment, concentrate and king grass (T2) was same effect on daily weight gain with feeding concentrate, king grass, wafer supplement (T4). The treatment had significantly effect on daily weight gain of local calf

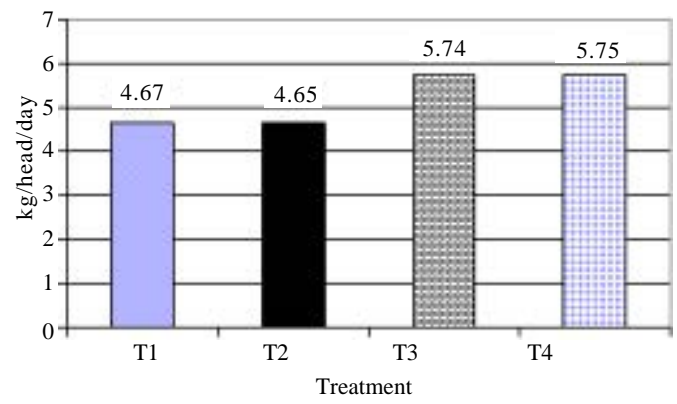

Fig. 2: Dry matter consumption

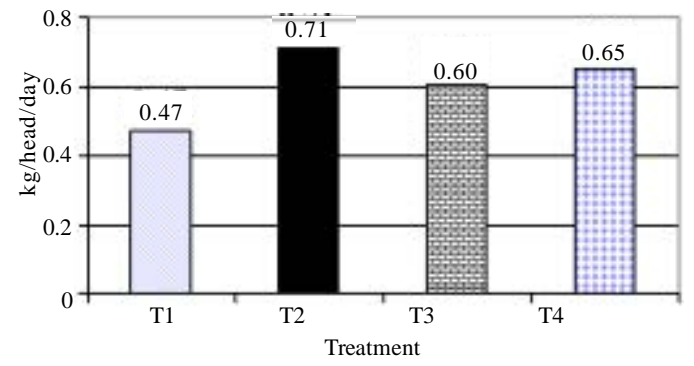

Fig. 3: Average protein intake 


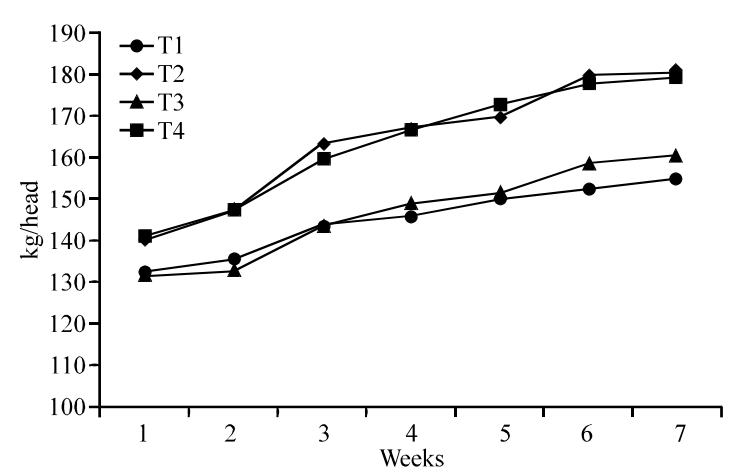

Fig. 4: Total protein consumption

compared to the other treatments. The daily weight gain of local calves (T2 and T4) had 42-45\% higher than the daily weight gain of conventional feeding.

Daily weight gain was influenced by several factors, i.e., the total consumption of protein, sex, age, genetic, environmental, physiological condition of livestock and management (Batubara, 2000). Feeding behaviors have been evaluated to understand mechanisms controlling feed intake regulation (NRC., 1985). Forage is important in high concentrate finishing diets to help maintain rumen function and prevent ruminal acidosis (Tolkamp et al., 2000). Adaptations in feeding behavior may be associated with changes in the rumen environment. Increasing the frequency and distribution of meals throughout the day can moderate ruminal $\mathrm{pH}$ (NRC., 1985), resulting in a reduced time when rumen $\mathrm{pH}$ is low. Daily weight gain of local calves by feeding wafer feed supplement (g/head/day) was shown in Table 1.

Body weight: The result showed that wafer feed supplement treatment was not significant $(p>0.05)$ on body weight of local calves and also did not have significant effect ( $p>0.05$ ) in block body weight of local calves. Local calves were fed by conventional fed had final body weight $161.67 \mathrm{~kg}$ meanwhile local calves were fed wafer supplement before conventional fed had $191.33 \mathrm{~kg}$ or $18.35 \%$ higher than conventional. The behavior of the calves ate one of which can be affected by low rumen $\mathrm{pH}$ caused by excessive consumption of concentrate being offset by the consumption of forage. Concentrate feed excessive in cattle can lead to increased fermentation of starch and will affect the ability of absorption of excess in the rumen and thus a decrease in rumen $\mathrm{pH}$ became acidic. Observed a high correlation between the behavior of feeding the cows with feed intake and rumen $\mathrm{pH}$ which indicates that the cow can adjust feed intake when a low rumen $\mathrm{pH}$ (Galyean and Defoor, 2003).
Table 1: Daily weight gain of local calves by feeding wafer feed supplement (g/head/day)

\begin{tabular}{|c|c|c|c|c|}
\hline \multirow[b]{2}{*}{ Treatment } & \multicolumn{3}{|c|}{ Block } & \multirow[b]{2}{*}{ Average } \\
\hline & B1 & B2 & B3 & \\
\hline $\mathrm{T} 1$ & 0.50 & 0.59 & 0.50 & $0.53 \pm 0.05^{a}$ \\
\hline $\mathrm{T} 2$ & 1.04 & 1.18 & 0.55 & $0.92 \pm 0.32^{b}$ \\
\hline T3 & 0.68 & 0.71 & 0.86 & $0.75 \pm 0.09^{\mathrm{a}}$ \\
\hline $\mathrm{T} 4$ & 0.86 & 0.89 & 1.16 & $0.97 \pm 0.16^{b}$ \\
\hline \multicolumn{5}{|c|}{ 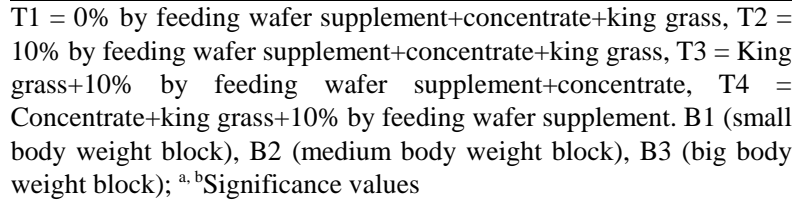 } \\
\hline
\end{tabular}

Dry matter and organic matter digestibility: Digestibility is the amount of feed that can be absorbed by the livestock (Brown et al., 2000). Value of digestibility of feed is an attempt to determine the amount of nutrients that feed material can be degraded and absorbed in the digestive tract of farm animals (Anggorodi, 1994). Adequate feed protein content and finer size of the structure can increase the amount of food consumption means that it will increase the digestibility of feed (Mcdonald et al., 2002). Factors affecting the digestibility of feed they are animal species, age, feed treatment, crude fiber and lignin content, nutrient deficient, feed ingredients, the physical form of feed, feed level and age of the plant (Martawidjaja and Gatenby, 1986). Digestibility of feed can be seen from dry matter and organic matter digestibility.

The results of dry matter and organic matter digestibility in local calves was shown in Table 2. Dry matter digestibility of feed given to the shows the degree of usefulness of the feed. Feeding patterns wafer feed supplement have significant effect $(p<0.05)$ on the dry matter and organic matter digestibility of the feed. The value of the highest dry matter digestibility in treatment T4 of $76.85 \%$. Values higher of dry matter digestibility will increase the nutrients that can be utilized by the animal. Feeding pattern has an influence on the process of dry matter digestibility. Feeding of concentrate beginning in the morning with high protein content causing bacteria in the rumen can be increased. Rumen conditions were empty in the morning led to concentrate easily degraded in the rumen. Feeding wafer supplement the high-protein supplementation supports increasing the digestibility in the rumen. The lowest of dry matter digestibility was viewed in treatment T1 $60.02 \%$. The low value of dry matter due to the consumption of feed materials low in treatment $\mathrm{T} 1$. dry matter digestibility value in $\mathrm{T} 1$ is still in normal condition. In tropical regions like Indonesia value of dry matter digestibility is between $40-65 \%$. States that the value of dry matter digestibility normally between 55-65\% (Van Soest, 1994). Giving the wafer supplement 
J. Anim. Vet. Adv., 18 (8): 270-277, 2019

Table 2: The result of dry matter and organic matter digestibility (\%)

\begin{tabular}{lll}
\hline & \multicolumn{1}{c}{ Digestibility } & \\
Treatment & Dry matter & Organic matter \\
\hline T1 & $60.02 \pm 12.26$ & $62.48 \pm 11.92$ \\
T2 & $76.84 \pm 7.58$ & $78.68 \pm 7.02$ \\
T3 & $74.62 \pm 1.33$ & $76.80 \pm 1.39$ \\
T4 & $76.85 \pm 2.82$ & $78.51 \pm 10.65$ \\
\hline
\end{tabular}

$\mathrm{T} 1=0 \%$ by feeding wafer supplement+concentrate+king grass, $\mathrm{T} 2=$ $10 \%$ by feeding wafer supplement + concentrate + king grass $\mathrm{T} 3=$ King grass $+10 \%$ by feeding wafer supplement+concentrate $\mathrm{T} 4=$ Concentrate+king grass $+10 \%$ by feeding wafer supplement. B1 (small body weight block), B2 (medium body weight block) B3 (big body weight block)

can increase dry matter digestibility of feed. This is due to increased proteolytic bacteria because of feeding wafers containing high protein (Bakrie, 1996).

Organic matter digestibility have be related with a dry matter digestibility of feed (Preston and Leng, 1987). Dry matter digestibility can increase the digestibility of organic matter because most of the components of dry matter is organic matter, so that, more nutrients can be used to meet the nutritional needs of cattle for basic living and production. The organic material is the excess of dry matter and ash content through a heating process. Value of organic matter digestibility the highest of the treatment T2 $78.68 \%$. Feeding pattern can increase the organic matter digestibility of feed in line with a dry matter digestibility. The feeding of feed containing a high crude protein activates microbes in the rumenn (Jayanegara et al., 2010). Number of proteolytic bacteria in the rumen will be followed by the rise of high deamination process resulting in an increased value of the organic matter digestibility of feed. The value of the lowest organic matter digestibility namely in treatment $\mathrm{T} 1$ $62.48 \%$.

Organic matter digestibility of nutrients show the number of proteins, fats and carbohydrates that can be digested by cattle. The value of the organic matter digestibility of feed can indicate the quality of the feed consumed by livestock (Arora, 1989). Organic matter digestibility showed the availability of nutrients in livestock feed can be utilized (Sutardi, 1980). Feeding treatment can affect the digestibility of dry matter and organic matter digestibility and affect body weight gain in cattle.

The higher the value of dry matter and organic matter digestibility, so that, the higher the body weight gain of Sumba Ongole calves. Feeding pattern and feeding of wafer supplement may increase body weight gain in Sumba Ongole calves. The high body weight gain in Sumba Ongole calves indicate that the value to the nutrients in the feed can be absorbed well by the body Sumba Ongole calves.
Table 3: The results of the analysis of blood glucose local calves (mg/dL)

Block

\begin{tabular}{lrrrc} 
Treatment & B1 & B2 & B3 & Average \\
\hline T1 & 99.72 & 76.11 & 66.67 & $80.83 \pm 17.03$ \\
T2 & 89.44 & 50.83 & 80.83 & $73.70 \pm 20.27$ \\
T3 & 97.50 & 69.44 & 91.94 & $86.29 \pm 14.86$ \\
T4 & 106.67 & 69.72 & 87.78 & $88.05 \pm 18.47$ \\
\hline
\end{tabular}

$\mathrm{T} 1=0 \%$ by feeding wafer supplement + concentrate+king grass, $\mathrm{T} 2=$ $10 \%$ by feeding wafer supplement + concentrate + king grass, $\mathrm{T} 3=$ King grass $+10 \%$ by feeding wafer supplement+concentrate, $\mathrm{T} 4=$ Concentrate+king grass $+10 \%$ by feeding wafer supplement. B1 (small body weight block), B2 (medium body weight block), B3 (big body weight block)

Blood metabolite: Blood has an important role in the transportation and absorption of nutrients in the body of animals. The factors that could affect blood metabolites were age, the amount of nutrients, health, temperature, pathogenic microbial infections, stress and feeding patterns. Blood metabolite levels could be influenced from the feed with adequate nutrients. The content of blood metabolite one is cholesterol that is influenced by the feed given to livestock.

Glucose is one energy source that is readily absorbed by ruminant. Glucose has an important role to provide energy to the ruminant to daily activity. Ruminants required glucose to maintain the body's cells such as blood and muscle (Tillman et al., 1991). As well as protein, ruminants also, require glucose for all phases of life (Parakkasi, 1999). The results of the analysis of blood glucose of local calves shown in Table 3.

Feeding patterns wafer feed supplement did not show significant effect ( $>0.05)$ to the levels of glucose local calves. The lowest glucose content was in the treatment $\mathrm{T} 2$ and then followed $\mathrm{T} 1$ of $73.70 \mathrm{mg} / \mathrm{dL}$ and 80.83 $\mathrm{mg} / \mathrm{dL}$. Low levels of glucose in treatment T2 due to energy sources were not given at the beginning of the feeding. Feeding wafer feed supplement protein source with a low quantity in the beginning could not affect glucose levels in the blood of Sumba Ongole calves (Preston, 1995). Feeding energy source first in the morning could increase the absorption of nutrients such as glucose and protein feed (Kaswari et al., 2007). The strategy of feeding patterns the energy source of feed given to early feeding (Henning et al., 1993). Sources of energy generating efficiency of rumen microbial growth were higher. Sources of high energy at the beginning of feeding will affect the blood glucose levels local calves.

The most high glucose content was in $\mathrm{T} 4$ treatment of $88.05 \mathrm{mg} / \mathrm{dL}$. Feeding of energy resources in advance could affect nutrient concentrations that indicate correlations between degradation of carbohydrates in the body of animal. Glucose and cholesterol levels in the blood have the opposite correlation. The results of blood 
Table 4: The results of blood cholesterol analysis local calves (mg/dL) Block

\begin{tabular}{|c|c|c|c|c|}
\hline Treatment & B1 & B2 & B3 & Average \\
\hline $\mathrm{T} 1$ & 192.13 & 177.95 & 70.34 & $146.81 \pm 66.59$ \\
\hline $\mathrm{T} 2$ & 157.48 & 66.14 & 152.76 & $125.46 \pm 51.42$ \\
\hline T3 & 121.78 & 135.96 & 33 & $134.55 \pm 12.13$ \\
\hline $\mathrm{T} 4$ & 114.44 & 158.01 & 154.86 & $142.43 \pm 24.29$ \\
\hline \multicolumn{5}{|c|}{$\begin{array}{l}\mathrm{T} 1=0 \% \text { by feeding wafer supplement }+ \text { concentrate }+ \text { king grass, T2 = } \\
10 \% \text { by feeding wafer supplement }+ \text { +concentrate+king grass, T3 = King } \\
\text { grass }+10 \% \text { by feeding wafer supplement }+ \text { concentrate, T4 } \\
\text { Concentrate+king grass }+10 \% \text { by feeding wafer supplement. B1 (small } \\
\text { body weight block), B2 (medium body weight block), B3 (big body } \\
\text { weight block) }\end{array}$} \\
\hline
\end{tabular}

Table 5: Results of analysis of blood protein total local calves (g/dL) Block (kg)

Small body Medium body Big body

weight weight weight

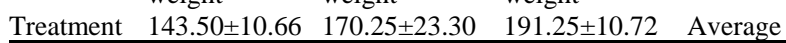

\begin{tabular}{lllll}
\hline T1 & 5.89 & 7.04 & 5.04 & $5.98 \pm 1.00$ \\
T2 & 4.91 & 6.36 & 5.85 & $5.70 \pm 0.74$ \\
T3 & 6.13 & 5.91 & 6.13 & $6.06 \pm 0.13$ \\
T4 & 5.92 & 5.32 & 9.68 & $6.97 \pm 2.36$ \\
\hline
\end{tabular}

$\mathrm{T} 1=0 \%$ by feeding wafer supplement+concentrate+king grass, $\mathrm{T} 2=$ $10 \%$ by feeding wafer supplement + concentrate+king grass, $\mathrm{T} 3=$ King grass $+10 \%$ by feeding wafer supplement+concentrate, $\mathrm{T} 4=$ Concentrate+king grass $+10 \%$ by feeding wafer supplement. B1 (small body weight block), B2 (medium body weight block), B3 (big body weight block)

glucose analysis in cattle between 43-100 mg/dL (Mitruka and Rawnsley, 1977). Treatment with feeding patterns with wafer feed supplement still under normal conditions in accordance with the literature.

Results of the analysis showed not significant effect ( $>0.05$ ) of cholesterol levels in the blood local calves. The cholesterol content of the highest of treatment T1 $146.81 \mathrm{mg} / \mathrm{dL}$. Lowest blood cholesterol content in treatment of T2 $125.46 \mathrm{mg} / \mathrm{dL}$. The cholesterol content of blood in local calves is in the normal range according to the literature. The cholesterol content in the blood of normal in cattle between 80-170 mg/dL (Duncan, 1986). The cholesterol content of blood cattle around 80-180 mg/dL (Murray et al., 2003). Feeding patterns wafer feed supplemen yet can lower blood cholesterol content in local calves. Cholesterol is a fatty substance produced by the liver and then flowed in the blood (Stercova et al., 2005). The results of blood cholesterol analysis local calves was shown in Table 4.

Total protein in the blood is influenced by the levels of protein in the feed consumed by animal. Proteins have an important role to ruminant live. Production of ruminant animals can not be separated from the consumption of high protein feed. The high consumption of feed with a protein can increase the production of cattle. Feed with high protein content will increase the protein content in the blood. The results of blood protein total analysis local calves was shown in Table 5.
Feeding with high protein content in cattle will significantly affect the total concentration of protein in the blood (Kolver et al., 1998). The treatment has not significant effect $(p>0.05)$ on the protein blood total. The highest blood protein total is in the treatment of T4 $6.97 \mathrm{mg} / \mathrm{dL}$ with other treatment. Different feeding patterns will indirectly affect the microbial protein synthesis in the rumen of cattle (Thrall, 2004). The total amount of protein in the blood of cattle affected by the concentration of albumin and globulin. The content of total protein in the blood that is normal in beef cattle between 5.7-8.1 mg/dL (Radostits et al., 2007).

This study discover the process of wafer can decrease mimosin of lamtoro leaf and pattern of feeding wafer feed supplement take effect of productivity of local calves that can be beneficial for smallholder farm to increase income over feed cost. This study will help the researcher to uncover the critical areas of wafer feed supplement and pattern of feeding that many researchers were not able to explore. Thus, a new theory on pattern off feeding wafer feed supplement may be arrived at. This study discovers the possible synergistic effect of high protein of wafer feed supplement and pattern of feeding can increase of daily weight gain of local calves. This study will help the researcher to uncover the quality of carcass of local calves that many researchers were not able to explore. Thus, a new theory on these technology of wafer and pattern of feeding wafer supplement on local calves, may be arrived at.

\section{CONCULSION}

It was concluded that feeding pattern wafer feed supplement can increase consumption and not influence condition of local calves. It was concluded that daily weight gain by feeding wafer supplement feed 42-45\% higer than conventional feed. High crude protein of wafer feed supplement is good supplement for ruminant in the tropic.

\section{REFERENCES}

Agustinus, M., 2016. [Questions about the need for beef, Ministry of Agriculture and the office of the coordinating minister for the economy different data]. Detik Finance, Jakarta, Indonasia. (In Indonasian) https://finance.detik.com/ekonomi-bisnis/3148131/ soal-kebutuhan-daging-sapi-kementan-dan-kantormenko-perekonomian-beda-data

Anggorodi, R.R., 1994. Feed Science. PT Gramedia, Jakarta, Indonesia,.

Arora, S.P., 1989. Microbial Digestion in Ruminants. UGM Press, Yogyakarta, Indonesia,. 
Bakrie, B., 1996. Ruminant Nutrition and Production in the Tropics and Subtropics. Australian Centre for International Agricultural Research, Canberra, Australia, ISBN:9781863201667, Pages: 151.

Batubara, A.A., 2000. Bioplus effect of Bali cattle. United States Department of Agriculture, Washington, DC., USA.

Brown, M.S., C.R. Krehbiel, M.L. Galyean, M.D. Remmenga and J.P. Peters et al., 2000. Evaluation of models of acute and subacute acidosis on dry matter intake, ruminal fermentation, blood chemistry and endocrine profiles of beef steers. J. Anim. Sci., 78: 3155-3168.

Chandra, A.A., 2016. [Meat consumption in Argentina 55 Kg/Capita, RI just 2.61 Kg]. Detik Finance, Jakarta, Indonasia. (In Indonasian) https://finance.detik. com/ekonomi-bisnis/3150082/konsumsi-daging-diargentina-55-kg-kapita-ri-cuma-261-kg

Devendra, C. and M. Burns, 1994. Goat Production in the Tropics. Institut Pertanian Bogor, Bogor, Indonesia,.

Duncan, J.R., 1986. Clinical Pathology. 2nd Edn., Ohio State University, Columbus, Ohio,.

Folin, O. and H. Wu, 1920. A system of blood analysis Supplement I: A simplified and improved method for determination of sugar. J. Biol. Chem., 41: 367-374.

Galyean, M.L. and P.J. Defoor, 2003. Effects of roughage source and level on intake by feedlot cattle. J. Anim. Sci., 81: E8-E16.

Hartadi, H., S. Reksohadiprodjo and A.D. Tillman, 1986. Feed Composition Table for Indonesia. 2nd Edn., Gadjah Mada University Press, Yogyakarta, Indonesia,.

Henning, P.H., D.G. Steyn and H.H. Meissner, 1993. Effect of synchronization of energy and nitrogen supply on ruminal characteristics and microbial growth. J. Anim. Sci., 71: 2516-2528.

Jayanegara, A., A.S. Tjakradidjaja and T. Sutardi, 2010. [Fermentability and in vitro digestibility of the ration supplemented with chromium waste agroindustrial the organic and inorganic (In Indonesian)]. Anim. Husbandry, 29: 54-62.

Kaswari, T., P. Lebzien, G. Flachowsky and U.T. Meulen, 2007. Studies on the relationship between the synchronization index and the microbial protein synthesis in the rumen of dairy cows. Anim. Feed Sci. Technol., 139: 1-22.

Kearl, L.C., 1982. Nutrient Requirements of Ruminants in Developing Countries. Utah State University, Logan, Utah, ISBN:9780874211160, Pages: 381.

Kolver, E., L.D. Muller, G.A. Vaga and T.J. Cassidy, 1998. Synchronization of ruminal degradation of supplemental carbohydrate with pasture nitrogen in lactating dairy cows. J. Dairy Sci., 81: 2017-2028.
Martawidjaja, M. and R.M. Gatenby, 1986. Comparation of the thermal budgets of five different roof of animal house. Applied Agriculture Research Project and Research Institut of Animal Production, Bogor, Java, Indonesia.

Mcdonald, P., R.A. Edwards, J.F.D. Greenhalgh and C.A. Morgan, 2002. Animal Nutrition. 6th Edn., Prentice Hall, Upper Saddle River, New Jersey, USA., ISBN:9788131717608, Pages: 693.

Mitruka, B.M. and H.M. Rawnsley, 1977. Clinical Biochemical and Hematological Reference Values in Normal Experimental Animals. Masson Publ., New York, USA., ISBN-13: 9780893520069, Pages: 272.

Murray, R.K., D.K. Granner, P.A. Mayes and V.W. Rodwell, 2003. [Harper Biochemistry]. 25th Edn., EGC Medical Book Store, North Jakarta, Indonesia, (In Indonesian).

NRC., 1985. Nutrient Requirement of Sheep. 6th Edn., National Academy Press, Washington DC, USA., Pages: 99.

Parakkasi, A., 1999. Nutrition and Feed Sciences Ruminants. University of Indonesia Press, Jakarta, Indonesia,.

Preston, T.R. and R.A. Leng, 1987. Matching Ruminant Production System with Available Sources in Tropics. Penabul Book, Armidale, Australia, ISBN:9780958829014, Pages: 245.

Preston, T.R., 1995. Tropical Animal Feeding a Manual for Research Worker. Food and Agriculture Organization of the United Nations, Rome, Italy, ISBN:9789251037584, Pages: 305.

Radostits, O.M., C.C. Gay, K.W. Hinchcliff and P.D. Constable, 2007. Veterinary Medicine: A Textbook of the Diseases of Cattle, Horses, Sheep, Pigs and Goats. 10th Edn., Saunders Elsevier, St. Louis, Missouri, Pages: 708.

Retnani, Y., F.P. Syananta, L. Herawati, W. Widiarti and A. Saenab, 2010. Physical characteristic and palatability of market vegetable waste wafer for sheep. J. Anim. Prod., 12: 29-33.

Retnani, Y., I.G. Permana and L.C. Purba, 2003. Physical characteristic and palatability of bio-supplement biscuit for dairy goat. Pak. J. Biol. Sci., 15: 83-88.

Retnani, Y., S. Andi and Taryati, 2014. Vegetable waste as wafer feed for increasing productivity of sheep. Asian J. Anim. Sci., 8: 15-23.

Siregar, S.B., 1995. Ruminant for feed. Penebar Swadaya, Jakarta, Indonesia. (In Indonesian)

Soebarinoto, C. and S.D. Mashudi, 1991. Ruminant nutrition science. Master Thesis, Department of Animal Nutrition and Feed, Brawijaya University, Malang, Indonesia. 
Soeparno, 1994. Science and Technology of Meat. Gadjah Mada University Press, Yogyakarta, Indonesia,.

Steel, R.G.D. and J.H. Torrie, 1993. Principles and Procedures of Statistic. 2nd Edn., McGraw Hall, New York, USA.,.

Stercova, E., V. Pazout, E. Strakova and P. Suchy, 2005. Effect of intensive fattening of bulls based on a high-grain diet on growth intensity and biochemical and acid-base parameters of blood. Czech J. Anim. Sci., 50: 355-361.

Sutardi, T., 1980. The foundation of nutrition science. Master Thesis, Bogor Agricultural University, Bogor, Java, Indonesia.

Syahwani, R., 2004. Effect of feeding method and the addition of probiotics in feed intake and digestibility of the crude fiber in sheep. Master Thesis, Bogor Agricultural University, Bogor, Indonesia.
Thrall, M.A., 2004. Laboratory Evaluation of Plasma and Serum Protein. In: Veterinary Hematology and Clinical Chemistry, Thrall, M.A., D.C. Baker and E.D.D. Lassen (Eds.). Lippincott Williams and Wilkins, Philadelphia, pp: 401-415.

Tilley, J.M.A. and R.A. Terry, 1963. A two-stage technique for the in vitro digestion of forage crops. Grass Forage Sci., 18: 104-111.

Tillman, D.A., H. Hartadi, S. Reksohadiprodjo and S. Lebdosoekojo, 1991. Feed animal science association. Master Thesis, Gadjah Mada University, Yogyakarta, Indonesia.

Tolkamp, B.J., D.P.N. Schweitzer and I. Kyriazakis, 2000. The biologically relevant unit for the analysis of short-term feeding behavior of dairy cows. J. Dairy Sci., 83: 2057-2068.

Van Soest, P.J., 1994. Nutritional Ecology of the Ruminant. 2nd Edn., Cornell University Press, London, UK., Pages: 476.

Zak, B., 1957. Simple and rapid microtechnique for serum total cholesterol. Am. J. Clin. Path., 27: 583-588. 